\title{
Una historia del eurocentrismo científico
}

\author{
A history of scientific Eurocentrism
}

\author{
Marcos Cueto ${ }^{i}$ \\ Pesquisador, Casa de Oswaldo Cruz/Fiocruz. \\ orcid.org/0000-0002-9291-7232 \\ marcos.cueto@fiocruz.br
}

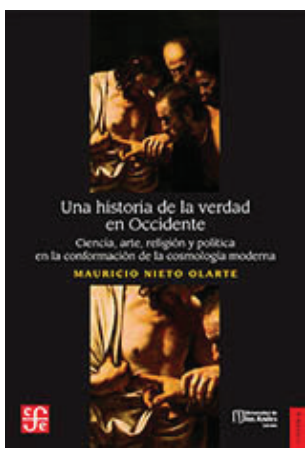

NIETO OLARTE, Mauricio. Una historia de la verdad en Occidente: ciencia, arte, religión y política en la conformación de la cosmología moderna. Bogotá: Fondo de Cultura Económica; Universidad de los Andes. 2019. 592 p.
Un destacado historiador de la ciencia es el autor de este libro, un colombiano quien previamente había producido valiosos análisis sobre las expediciones científicas y el naturalismo en España y América en las postrimerías del período colonial (Nieto Olarte, 2006, 2007). En este ambicioso trabajo analiza el desarrollo del conocimiento racional y la emergencia del eurocentrismo político, cultural y científico a partir del siglo XVIII. La mayoría de los 21 capítulos de este estudio se concentran en los saberes producidos en Europa durante la Edad Moderna (1492-1789). Es decir, se ocupan de temas como el Renacimiento italiano, la astronomía de Galileo, el empirismo de Francis Bacon y la física de Isaac Newton. Los capítulos iniciales se remontan a las discusiones filosóficas de Platón y Aristóteles sobre los límites y la esencia del conocimiento, así como a la noción de una única verdad del monoteísmo cristiano. En sus capítulos finales aborda la construcción del carácter enciclopédico de la obra de Alexander von Humboldt y hace un recuento del positivismo de Auguste Comte. Para encontrar

una obra de envergadura parecida en América Latina es necesario remontarse a Aldo Mieli (1952), el inmigrante italiano que publicó en varios volúmenes una historia de la ciencia europea en la Argentina de los años 1950. Luego de este esfuerzo, la mayoría de los historiadores latinoamericanos de la ciencia y de la medicina nos ocupamos de la recepción, la negociación y la participación de investigadores latinoamericanos en circuitos internacionales del conocimiento.

La diversidad temática y temporal de los asuntos tratados por Nieto Olarte no sacrifica la profundidad ni la coherencia de su análisis. Es un libro relevante por varias razones. En primer lugar, porque explora de una manera creativa y sugerente la estrecha relación de la construcción y difusión de la verdad científica con el arte, la filosofía, la religión, la política e inclusive la magia. Durante la mayor parte del pasado, no existieron barreras fijas 
o compartimientos estanco que separasen lo que hacían pintores, ingenieros, médicos y los cultores de lo que hemos venido a llamar conocimiento científico. Según Nieto Olarte, solamente a comienzos del siglo XIX se empiezan a construir fronteras entre las diferentes formas de saber y a establecer diferencias y jerarquías entre sus practicantes. Entonces, se glorificó y se proyectó, tanto hacia el pasado como hacia el futuro, el empirismo y el racionalismo. Al mismo tiempo se consolidó una narrativa tradicional de historia de la ciencia que asignaba a la Inglaterra del siglo XVII el origen casi exclusivo de la ciencia moderna.

Una segunda razón por la que este trabajo es pertinente es porque enfatiza los procesos más que los orígenes en la historia del conocimiento; procesos adonde las continuidades son más importantes que los cambios. Estas continuidades y procesos son generalmente incoherentes, contradictorios, heterodoxos y hasta disonantes. De esta manera, Nieto Olarte se une a la voz de otros historiadores que sostienen que el Renacimiento, como una categoría distintiva del pasado, es un mito y la Revolución Científica de Inglaterra del siglo XVII es un concepto que por lo menos debe ser pensado en una versión plural. Nieto Olarte también se suma a otros autores cuando subraya que el eurocentrismo es un concepto y una realidad atractiva y poderosa para quienes supuestamente serian víctimas del mismo porque es incluyente: es decir asimila, de una manera subordinada, a otras culturas fuera de Europa. De acuerdo con Nieto Olarte, casi todo el resto de culturas - agregaríamos que la mayoría de las sociedades latinoamericanas durante buena parte de su historia - aceptan y refuerzan el ideal al que deben aspirar minimizando los cuestionamientos a este modelo. En tercer lugar, este estudio es importante porque explica cómo las prácticas y las técnicas - como el astrolabio, la cartografía, el telescopio, los museos y la imprenta - moldearon el contenido del conocimiento.

Sin duda la atención del autor está alrededor de las diferentes formas de historia intelectual. Aunque hay oportunas referencias a la relación entre los grandes centros comerciales y el imperialismo europeo con la ciencia, este libro no es una historia social de la ciencia. Y no necesita serlo para ser una contribución notable. Una de sus cualidades es la clara explicación de la evolución de los argumentos de diferentes historiadores de la ciencia que en los últimos años han cuestionado la importancia de la Revolución Científica del siglo XVII como un momento fundacional realizado por una élite. Es también importante mencionar otro de los límites que Nieto Olarte reconoce y que es una paradoja en el resultado final del trabajo: no es un estudio de formas alternativas al saber del europeo occidental - a pesar de que existe un capítulo sobre el Islam y la ciencia en el Medio Oriente. Es decir, a pesar que el libro cuestiona la hegemonía europea en las narrativas tradicionales de historia de la ciencia acaba ocupándose principalmente de lo que pasó en el viejo continente. También el autor reconoce que está contando una historia plagada de hombres y en la que la contribución de las mujeres fue y es invisibilizada. Sin embargo, es necesario reconocer que pedir a un estudio que cubra todo no es solo injusto sino imposible.

En este valioso estudio, los historiadores de la ciencia y los lectores en general podrán reflexionar sobre la constante reproducción de la fragmentación del saber académico, lo cual limita el entendimiento de la relación entre la naturaleza y la sociedad y de la interacción entre todas las formas humanas de aprender, experimentar y conocer. Aquellos interesados en la historia de la salud tendrán especial interés en la sección sobre René Descartes y la 
diferenciación radical entre la mente y los mecanismos del cuerpo humano. La bibliografía final es un recuento actualizado de las investigaciones contemporáneas y clásicas que será valorada por otros historiadores. La inclusión de pequeños recuadros biográficos, diseños, reproducciones de pinturas, mapas y cronología hacen el texto accesible y susceptible de ser usado en cursos universitarios.

¿Podrá la lectura de este trabajo darle mayor densidad y horizonte teóricos a los historiadores y filósofos latinoamericanos que se ocupan de la ciencia y la evolución del conocimiento? Ojalá.

\section{REFERENCIAS}

MIELI, Aldo.

Panorama general de historia de la ciencia: la época medieval, mundo islámico y occidente cristiano. Buenos Aires: Espasa-Calpe. 1952.

NIETO OLARTE, Mauricio.

Una historia de la verdad en Occidente: ciencia, arte, religión y política en la conformación de la cosmología moderna. Bogotá: Fondo de Cultura Económica; Universidad de los Andes. 2019.
NIETO OLARTE, Mauricio.

Orden natural y orden social: ciencia y política en el Semanario del Nuevo Reyno de Granda. Madrid: Consejo Superior de Investigaciones Científicas. 2007.

NIETO OLARTE, Mauricio.

Remedios para el imperio: historia natural y la apropiación del nuevo mundo. Bogotá: Universidad de los Andes. 2006. 